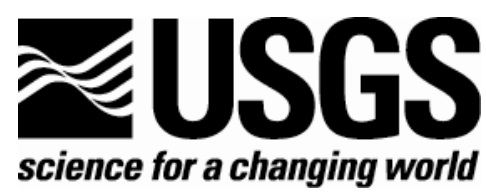

\title{
Digital data and derivative products from a high- resolution aeromagnetic survey of the central San Luis basin, covering parts of Alamosa, Conejos, Costilla, and Rio Grande Counties, Colorado, and Taos County, New Mexico
}

By Viki Bankey, V.J.S. Grauch, Ank Webbers, and PRJ, Inc.

Any use of trade, firm, or product names is for descriptive purposes only and does not imply endorsement by the U.S. Government

Open-File Report 2005-1200

U.S. Department of the Interior

U.S. Geological Survey 


\title{
U.S. Department of the Interior
}

\author{
Gale A. Norton, Secretary
}

\section{U.S. Geological Survey \\ Charles G. Groat, Director}

U.S. Geological Survey, Reston, Virginia 2005

Revised and reprinted: 2005

For product and ordering information:

World Wide Web: http://www.usgs.gov/pubprod

Telephone: 1-888-ASK-USGS

For more information on the USGS - the Federal source for science about the Earth, its natural and living resources, natural hazards, and the environment:

World Wide Web: http://www.usgs.gov

Telephone: 1-888-ASK-USGS

Although this report is in the public domain, permission must be secured from the individual copyright owners to reproduce any copyrighted material contained within this report. 


\title{
Digital data and derivative products from a high-resolution aeromagnetic survey of the central San Luis basin, covering parts of Alamosa, Conejos, Costilla, and Rio Grande Counties, Colorado, and Taos County, New Mexico
}

by

Viki Bankey, V.J.S. Grauch, Ank Webbers, and PRJ, Inc.

\begin{abstract}
This CD-ROM contains digital data, image files, and text files describing data formats and survey procedures for aeromagnetic data collected during a high-resolution aeromagnetic survey in southern Colorado and northern New Mexico during October, 2004. The survey covers the central San Luis basin in Alamosa, Conejos, Costilla, and Rio Grande Counties, Colorado, and Taos County, New Mexico. Several derivative products from these data are also presented as grids and images, including reduced-to-pole data, first vertical derivative, and data continued to a reference surface. Images are presented in various formats, intended as input to geographic information systems, standard graphics software, or map plotting packages. The variety of formats also accommodates viewing at 1:100,000 or 1:24,000 map scales.

\section{Introduction}

This report describes data collected from a high-resolution aeromagnetic survey flown over the central San Luis basin during October, 2004, by PRJ, Inc., on contract to the U.S. Geological Survey (USGS). The survey extends from just north of Alamosa, Colorado, southward to just northwest of Taos, New Mexico. It covers large parts of the San Luis Valley in Alamosa, Conejos, Costilla, and Rio Grande Counties, southern Colorado, and the Taos Plateau in Taos County, northern New Mexico (fig. 1). The survey was designed to complement two surveys previously acquired along the eastern borders of the San Luis Basin over the vicinities of Taos, New Mexico (Bankey and others, 2004a) and Blanca, Colorado (Bankey and others, 2004b). Our overall objective in conducting these surveys is to improve knowledge of the subsurface geologic framework in order to understand ground-water systems in populated alluvial basins along the Rio Grande. These USGS efforts are conducted in collaboration with other federal, state, and local governmental entities where possible.
\end{abstract}




\section{Organization of CD-ROM}

The files on this CD-ROM and the contents of the folders (directories) are briefly explained in Table 1. The "readme.txt" file provides summaries of the contents of the CD-ROM. The folders (directories) are organized as follows. Files pertaining to this report are contained in the "report" folder; files pertaining to the gridded data are contained in the "grids" folder; files pertaining to the flight-line data are contained in the "linedata" folder; and files pertaining to the color shadedrelief images are contained in the "images" folder. In the data folders, ASCII files with the extension ".txt" describe the format and contents of the data files. Please read the ".txt" files before using the data files.

\section{Description of Data}

Aeromagnetic data are collected using airborne geophysical sensors that measure subtle variations in the Earth's magnetic field. Aeromagnetic surveys are designed to map variations caused by differences in the magnetic properties of rocks. High-resolution surveys are flown closer to the ground and with narrower line spacing than conventional aeromagnetic surveys to better detect weakly magnetic rocks.

The aeromagnetic survey for the central San Luis basin (fig. 1) employed a fixed-wing aircraft flying along traverse lines oriented east-west, spaced $200 \mathrm{~m}$ (about $650 \mathrm{ft}$ ) apart, and flown a nominal $150 \mathrm{~m}(500 \mathrm{ft}$ ) above ground. Orthogonal lines were flown north-south at a 1,000 m (3,280 ft) spacing. Total flight-line coverage involved 2,522 line kilometers (1,567 line miles). The east-west orientation of traverse lines was chosen because it is oblique to the predominant northerly geologic strike of the area. The flight-line data from the contractor are included in this report. Contractor-provided details of the flight specifications, survey procedures, and data processing are included in Appendix A.

Topographic and radar altimeter gridded data are also provided. The topographic grid was created from 1-arc-second $(30 \mathrm{~m})$ digital elevation data that were resampled to $50 \mathrm{~m}$.

\section{Derivative Products}

\section{Reduced-to-pole Magnetic Data}

The residual magnetic field channel had already been properly corrected using the Definitive Geomagnetic Reference Field by the contractors, so no further main field corrections were necessary before gridding. The data were interpolated onto a grid at $50 \mathrm{~m}$ intervals. Projection is UTM, zone $13 \mathrm{~N}$ (central meridian of $105^{\circ} \mathrm{W}$. long., a false easting of 500,000 m, a false northing of $0 \mathrm{~m}$, and using the NAD27 datum). The reduction-to-pole (RTP) transformation corrects for the offset between the locations of anomalies (closed highs or lows on a contour map) and their sources that is a consequence of the vector nature of the Earth's magnetic field (Blakely, 1995). To apply the reduced-to-pole transformation, one must assume that the total magnetizations of most rocks in the study area align parallel or anti-parallel to the Earth's main field (declination $=10^{\circ}$, inclination $=64^{\circ}$ for the study area). Based on considerations of rock type and age in the area, this assumption is generally valid (Grauch and others, 2004). 


\section{Continued Reduced-to-pole Magnetic Data}

To enhance details, the gridded RTP magnetic data were continued from the variable observation surface to a reference surface $100 \mathrm{~m}$ above ground, using the chessboard method of Cordell (1985) as implemented by the commercial software package, OASIS Montaj ${ }^{\mathrm{TM}}$, augmented with USGS-developed algorithms (Phillips and others, 2003). In the chessboard method, the continued data are extrapolated from a series of parallel continuation surfaces that each have been computed using standard Fast Fourier transform (FFT) techniques (e.g., Blakely, 1995). The radar-altimeter channel was used to create the terrain clearance grid, which, in turn, determined the distances to continue the data. Radar-altimeter data from the contractor were leveled using the tie-line data to better approximate the flight surface. Because the chessboard operation for this study mostly involves downward continuation, a lowpass filter (created using a cosine-squared rolloff function) was applied to minimize the amplification of noise. The severity of the filter was adjusted to account for the amount of downward continuation required in different areas. The continued, reduced-to-pole aeromagnetic data are presented as color shadedrelief images.

The continuation (reference) surface (cslcontsurfgrd.gxf) was constructed by adding both 100 meters and the difference between the actual radar altimeter and the levelled radar value to the terrain elevation.

Continuation surface $=$ terrain $+100+($ actual radar - levelled radar $)$

\section{First Vertical Derivative}

To enhance detailed patterns and linear features even further, we computed the first vertical derivative of the continued RTP data. The first vertical derivative is a standard geophysical technique based on potential-field theory and commonly computed using FFT techniques (e.g., Blakely, 1995). To minimize amplification of noise during the operation, a Butterworth filter with a cutoff wavelength of $200 \mathrm{~m}$ was applied. The first vertical derivative data are presented as color shaded-relief images.

\section{Merged Data for 1:24,000-scale Images}

The continued RTP data were merged with analogous data from the two pre-existing aeromagnetic surveys (Blanca and Taos helicopter surveys) to complete several of the images presented at 1:24,000 map scale (fig. 2) along the eastern side of the survey area. The data were merged using the suture method of knitting grids together in the Oasis Montaj program from Geosoft, Inc. Where data sets overlap, data from the helicopter surveys took priority. 


\section{Description of Digital Files}

Table 1. List of files, formats, and descriptions in this report.

\begin{tabular}{|c|c|c|}
\hline FILE NAME & FORMAT TYPE & DESCRIPTION \\
\hline readme.txt & ASCII text & $\begin{array}{l}\text { Text file explaining how to read and use the files of } \\
\text { this CD-ROM. }\end{array}$ \\
\hline \multicolumn{3}{|l|}{----- REPORT folder ----- } \\
\hline report.pdf & $\begin{array}{l}\text { portable document } \\
\text { format }\end{array}$ & $\begin{array}{l}\text { A file containing the text of this report, with hyperlink } \\
\text { to the appendix and figures. }\end{array}$ \\
\hline appendix.pdf & $\begin{array}{l}\text { portable document } \\
\text { format }\end{array}$ & $\begin{array}{l}\text { Contractor's report on the aeromagnetic data } \\
\text { collection. }\end{array}$ \\
\hline \multicolumn{3}{|l|}{----- GRIDS folder ----- } \\
\hline gxfinfo.txt & ASCII text & $\begin{array}{l}\text { Description of grids with the extension.gxf and } \\
\text { explanation of grid exchange format. }\end{array}$ \\
\hline $\begin{array}{l}\text { cslmaggrd.gxf } \\
\text { csl83maggrd.gxf }\end{array}$ & grid exchange format & $\begin{array}{l}\text { Leveled total-intensity magnetic data. (NAD27 and } \\
\text { NAD83 projections) }\end{array}$ \\
\hline $\begin{array}{l}\text { cslrtpgrd.gxf } \\
\text { csl83rtpgrd.gxf }\end{array}$ & grid exchange format & $\begin{array}{l}\text { Reduced-to-pole (RTP) magnetic data. (NAD27 and } \\
\text { NAD83 projections) }\end{array}$ \\
\hline $\begin{array}{l}\text { cslrtpcontgrd.gxf } \\
\text { csl83rtpcontgrd.gxf }\end{array}$ & grid exchange format & $\begin{array}{l}\text { Continued, reduced-to-pole (RTP) magnetic data. } \\
\text { Data were continued to a surface } 100 \mathrm{~m} \text { above ground. } \\
\text { (NAD27 and NAD83 projections) }\end{array}$ \\
\hline $\begin{array}{l}\text { cslrdrgrd.gxf } \\
\text { csl83rdrgrd.gxf }\end{array}$ & grid exchange format & $\begin{array}{l}\text { Leveled radar altimeter measurements. (NAD27 and } \\
\text { NAD83 projections) }\end{array}$ \\
\hline $\begin{array}{l}\text { cslcontsurfgrd.gxf } \\
\text { csl83contsurfgrd.gxf }\end{array}$ & grid exchange format & $\begin{array}{l}100 \text { m continuation surface (NAD27 and NAD83 } \\
\text { projections) }\end{array}$ \\
\hline $\begin{array}{l}\text { cslrtpcont1stvergrd.gxf } \\
\text { cs183rtpcont1stvergrd.gxf }\end{array}$ & grid exchange format & $\begin{array}{l}\text { First vertical derivative of the continued, reduced-to- } \\
\text { pole (RTP) magnetic data (NAD27 and NAD83 } \\
\text { projections). }\end{array}$ \\
\hline $\begin{array}{l}\text { csltopomgrd.gxf } \\
\text { csl83topomgrd.gxf }\end{array}$ & grid exchange format & $\begin{array}{l}\text { Topography data from 1-arc-second digital elevation } \\
\text { data (NAD27 and NAD83 projections). }\end{array}$ \\
\hline \multicolumn{3}{|l|}{-----LINEDATA folder ----- } \\
\hline linedata_info.txt & ASCII format & $\begin{array}{l}\text { Description of the information and format of the } \\
\text { flight-line data file. }\end{array}$ \\
\hline centralsanluis.asc & ASCII format & $\begin{array}{l}\text { Final information from the contractor as sampled } \\
\text { along the flight lines. }\end{array}$ \\
\hline \multicolumn{3}{|l|}{-----IMAGES folder ----- } \\
\hline imginfo.txt & ASCII text & $\begin{array}{l}\text { Description of the files containing color-shaded relief } \\
\text { images developed in ERMapper from the magnetic } \\
\text { data. }\end{array}$ \\
\hline $\begin{array}{l}\text { cslmag.tif } \\
\text { cslmag.tfw }\end{array}$ & $\begin{array}{l}\text { Tagged image format } \\
\text { Geotif ASCII header } \\
\text { file }\end{array}$ & $\begin{array}{l}\text { Color shaded-relief image of leveled total-intensity } \\
\text { magnetic data, and georegistration file. No text } \\
\text { annotation or scales. }\end{array}$ \\
\hline $\begin{array}{l}\text { cslrtp.tif } \\
\text { cslrtp.tfw }\end{array}$ & $\begin{array}{l}\text { Tagged image format } \\
\text { Geotif ASCII header } \\
\text { file }\end{array}$ & $\begin{array}{l}\text { Color shaded-relief image of reduced-to-pole (RTP) } \\
\text { magnetic data, and georegistration file. No text } \\
\text { annotation or scales. }\end{array}$ \\
\hline $\begin{array}{l}\text { cslrtpcont.tif } \\
\text { cslrtpcont.tfw }\end{array}$ & $\begin{array}{l}\text { Tagged image format } \\
\text { Geotif ASCII header } \\
\text { file }\end{array}$ & $\begin{array}{l}\text { Color shaded-relief image of continued, reduced-to- } \\
\text { pole (RTP) magnetic data, and georegistration file. } \\
\text { No text annotation or scales. }\end{array}$ \\
\hline $\begin{array}{l}\text { cslrtpcont } 1 \text { stver.tif } \\
\text { cslrtpcont } 1 \text { stver.tfw }\end{array}$ & $\begin{array}{l}\text { Tagged image format } \\
\text { Geotif ASCII header } \\
\text { file }\end{array}$ & $\begin{array}{l}\text { Color shaded-relief image of first vertical derivative } \\
\text { of the continued, reduced-to-pole (RTP) magnetic } \\
\text { data, and georegistration file. No text annotation or } \\
\text { scales. }\end{array}$ \\
\hline
\end{tabular}




\begin{tabular}{|l|l|l|}
\hline FILE NAME & FORMAT TYPE & DESCRIPTION \\
\hline $\begin{array}{l}\text { csltopom.tif } \\
\text { csltopom.tfw }\end{array}$ & $\begin{array}{l}\text { Tagged image format } \\
\text { Geotif ASCII header } \\
\text { file }\end{array}$ & $\begin{array}{l}\text { Color shaded-relief image of topography data from 1- } \\
\text { arc-second digital elevation data, and georegistration } \\
\text { file. No text annotation or scales. }\end{array}$ \\
\hline cslmag.pdf & $\begin{array}{l}\text { portable document } \\
\text { format }\end{array}$ & $\begin{array}{l}\text { Color shaded-relief image of leveled total-intensity } \\
\text { magnetic data, with annotations. }\end{array}$ \\
\hline cslrtp.pdf & $\begin{array}{l}\text { portable document } \\
\text { format }\end{array}$ & $\begin{array}{l}\text { Color shaded-relief image of reduced-to-pole (RTP) } \\
\text { magnetic data, with annotations. }\end{array}$ \\
\hline cslrtpcont.pdf & $\begin{array}{l}\text { portable document } \\
\text { format }\end{array}$ & $\begin{array}{l}\text { Color shaded-relief image of continued, reduced-to- } \\
\text { pole (RTP) magnetic data, with annotations. }\end{array}$ \\
\hline cslrtpcont1stver.pdf & $\begin{array}{l}\text { portable document } \\
\text { format }\end{array}$ & $\begin{array}{l}\text { Color shaded-relief image of first vertical derivative } \\
\text { of continued, reduced-to-pole (RTP) magnetic data, } \\
\text { with annotations. }\end{array}$ \\
\hline cslfllines.pdf & $\begin{array}{l}\text { portable document } \\
\text { format }\end{array}$ & Flight-line locations with flight-line numbers. \\
\hline csltopom.pdf & $\begin{array}{l}\text { portable document } \\
\text { format }\end{array}$ & $\begin{array}{l}\text { Color shaded-relief image of topography, with } \\
\text { annotations. }\end{array}$ \\
\hline
\end{tabular}

Table 2. List of 1:24,000-scale filenames, area names, and quadrangles (fig. 2)

\begin{tabular}{|c|c|c|c|}
\hline Filename & Quads covered & $\begin{array}{l}\text { preview filename } \\
\text { (.pdf) }\end{array}$ & $\begin{array}{l}\text { geotif filename } \\
\text { (.tif/.tfw) }\end{array}$ \\
\hline Alamosa East & Alamosa East, Hooper SE & cslAlamosaA & cslAlamosaE \\
\hline Alamosa West & $\begin{array}{l}\text { Alamosa West, } \\
\text { Mount Pleasant School }\end{array}$ & cslAlamosaW & cslAlamosaW \\
\hline Arroyo Hondo & $\begin{array}{l}\text { Arroyo Hondo, Arroyo Seco, } \\
\text { Los Cordovas, Taos }\end{array}$ & cslArroyoHndo & cslArroyoHndo \\
\hline Baldy & Baldy, Dry Lakes & cslBaldy & cslBaldy \\
\hline Blanca & Blanca, Twin Peaks & cslBlanca & cslBlanca \\
\hline Blanca SE & Blanca SE & cslBlancaSE & cslBlancaSE \\
\hline Capulin & Capulin, Centro & cslCapulin & cslCapulin \\
\hline Cerro De La Olla & Cerro De La Olla & cslCerDLaOlla & cslCerDLaOlla \\
\hline Cerro De Los Taoses & $\begin{array}{l}\text { Cerro De Los Taoses, } \\
\text { Tres Orejas }\end{array}$ & cslCerroDLTaoses & cslCerroDLTaoses \\
\hline Costilla & Costilla & cslCostilla & cslCostilla \\
\hline Fort Garland & Fort Garland, Blanca Peak & cslFtGarland & cslFtGarland \\
\hline Fort Garland SW & $\begin{array}{l}\text { Fort Garland SW, Ojito Peak, } \\
\text { San Luis, Taylor Ranch }\end{array}$ & cslFtGarlandSW & cslFtGarlandSW \\
\hline Garcia & Garcia & cslGarcia & cslGarcia \\
\hline Goshawk Dam & $\begin{array}{l}\text { Goshawk Dam, } \\
\text { Vicente Canyon }\end{array}$ & cslGshkDam & cslGshkDam \\
\hline Guadalupe Mountain & Guadalupe Mountain, Questa & cslGuadlpeMtn & cslGuadlpeMtn \\
\hline Kiowa Hill & Kiowa Hill & cslKiowaHill & cslKiowaHill \\
\hline La Jara & La Jara & cslLaJara & cslLaJara \\
\hline La Segita Peaks & $\begin{array}{l}\text { La Segita Peaks, } \\
\text { San Antonio Mountain }\end{array}$ & cslLaSegPks & cslLaSegPks \\
\hline
\end{tabular}




\begin{tabular}{|c|c|c|c|}
\hline La Segita Peaks NE & La Segita Peaks NE & cslLaSegPksNE & cslLaSegPksNE \\
\hline Lasauses & Lasauses & cslLasauses & cslLasauses \\
\hline Lobatos & Lobatos, Antonito & cslLobatos & cslLobatos \\
\hline Manassa & Manassa & cslManassa & cslManassa \\
\hline Manassa NE & Manassa NE & cslManassaNE & cslManassaNE \\
\hline Mesito Reservoir & Mesito Reservoir & cslMesitoRsvr & cslMesitoRsvr \\
\hline Petaca Peak & $\begin{array}{l}\text { Petaca Peak, Las Tablas, } \\
\text { Servilleta Plaza }\end{array}$ & cslPetacaPk & cslPetacaPk \\
\hline Pikes Stockade & Pikes Stockade & cslPksStckade & cslPksStckade \\
\hline Pinabetoso Peaks & Pinabetoso Peaks, Los Pinos & cslPinabtsPk & cslPinabtsPk \\
\hline San Acacio & San Acacio & cslSanAcacio & cslSanAcacio \\
\hline Sky Valley Ranch & Sky Valley Ranch & eslSkyVlyRnch & cslSkyVlyRnch \\
\hline Sunshine & Sunshine, Cerro & cslSunshine & cslSunshine \\
\hline Tres Piedras & Tres Piedras, Mule Canyon & cslTresPiedras & cslTresPiedras \\
\hline Tres Piedras NE & Tres Piedras NE & cslTresPiedrasNE & cslTresPiedrasNE \\
\hline Ute Mountain & Ute Mountain & cslUteMtn & cslUteMtn \\
\hline Waverly & $\begin{array}{l}\text { Waverly, Fulcher Gulch, } \\
\text { Home Lake, Monte Vista }\end{array}$ & cslWaverly & cslWaverly \\
\hline
\end{tabular}

\section{Acknowledgments}

We are thankful to the people of southern Colorado and northern New Mexico for their tolerance during the low-level flying over their homes and businesses. 


\section{References cited}

Bankey, Viki, Grauch, V.J.S., and Fugro Airborne Surveys Corp., 2004a, Digital aeromagnetic data and derivative products from a helicopter survey over the town of Taos and surrounding areas, Taos County, New Mexico: U.S. Geological Survey Open-File Report 2004-1229A, CD-ROM.

Bankey, Viki, Grauch, V.J.S., and Fugro Airborne Surveys Corp., 2004b, Digital aeromagnetic data and derivative products from the Blanca airborne survey, covering areas in Costilla and Alamosa County, Colorado: U. S. Geological Survey Open-file Report 2004-1229B, CD-ROM.

Blakely, R.J., 1995, Potential theory in gravity and magnetic applications: Cambridge University Press, 441 pp.

Cordell, L., 1985, Techniques, applications, and problems of analytical continuation of New Mexico aeromagnetic data between arbitrary surfaces of very high relief, Proceedings of the International Meeting on Potential Fields in Rugged Topography, Institute of Geophysics, University of Lausanne, Switzerland, Bulletin no. 7, p. 96-99.

Grauch, V.J.S., Bauer, P.W., and Kelson, K.I., 2004, Preliminary interpretation of high-resolution aeromagnetic data collected near Taos, New Mexico: New Mexico Geological Society Guidebook 55, p. 244-256.

Phillips, J.D., Duval, J.S, and Saltus, R.W., 2003, Geosoft eXecutables (GX's) developed by the U.S. Geological Survey, version 1.0, with a viewgraph tutorial on GX development: U.S. Geological Survey Open-File Report 03-010, http://pubs.usgs.gov/of/2003/ofr-03-010/ 


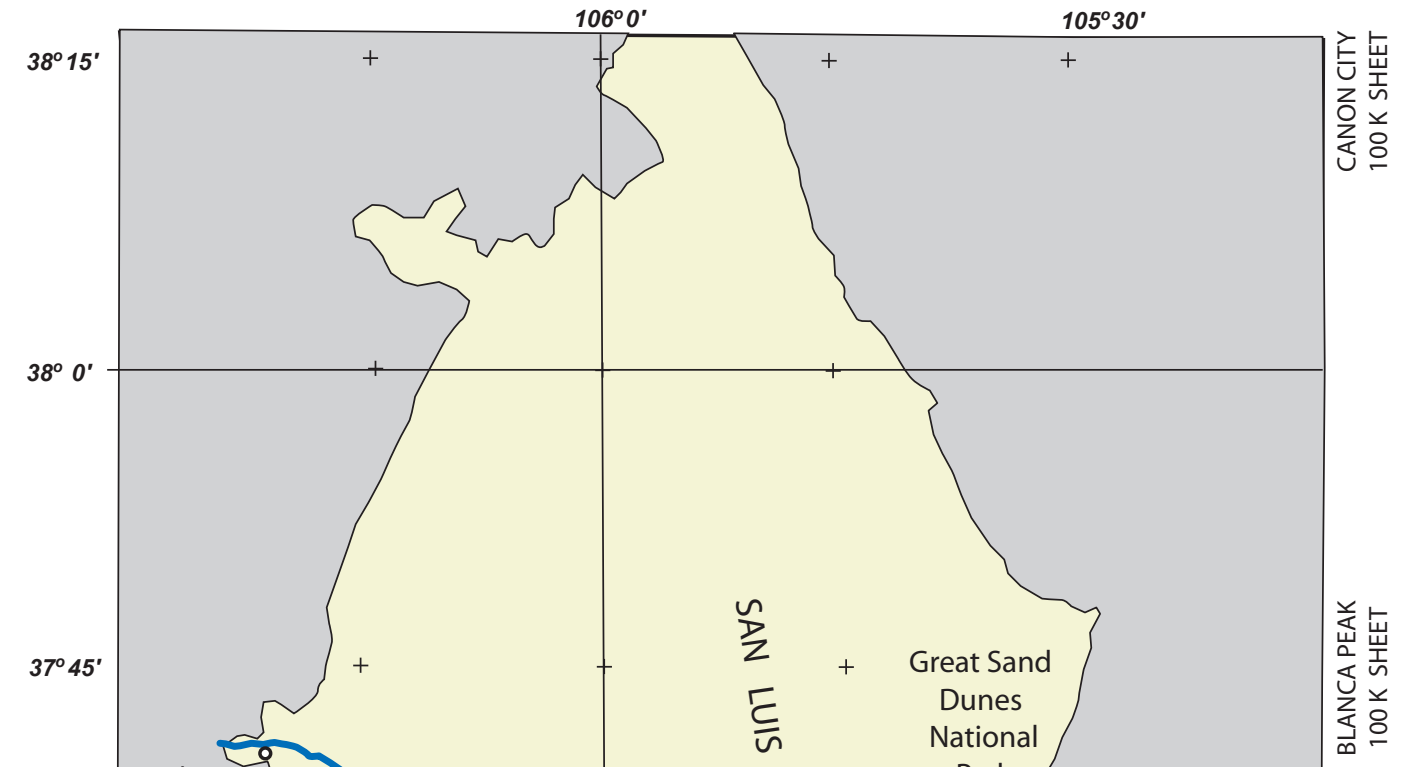

Figure 1. Location of aeromagnetic surveys (Central San Luis = red, this report; Blanca and Taos = gray)

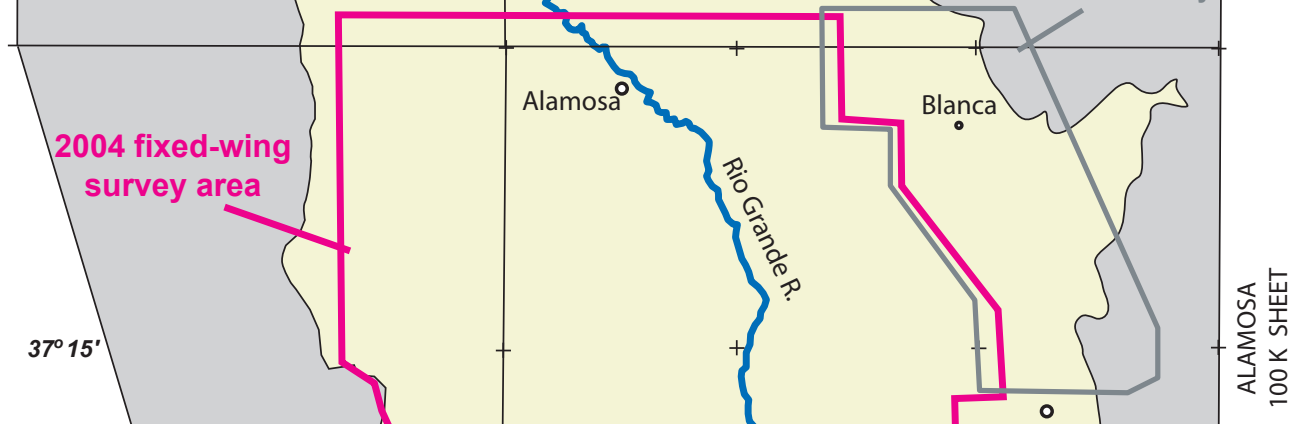

$37^{\circ} 0^{\circ}$

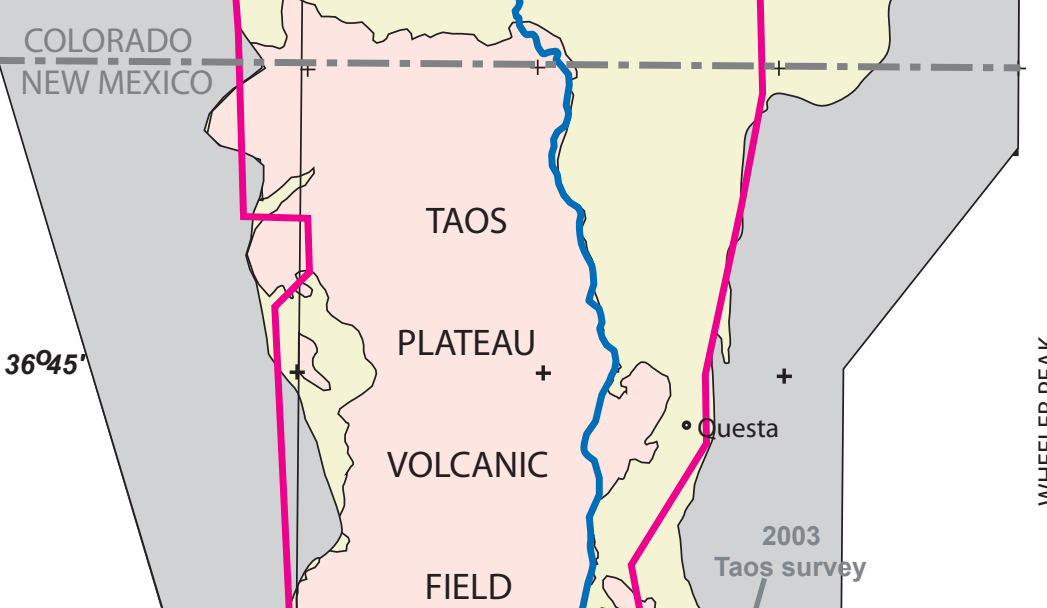

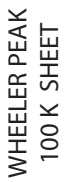

$36^{\circ} 30^{\prime}$

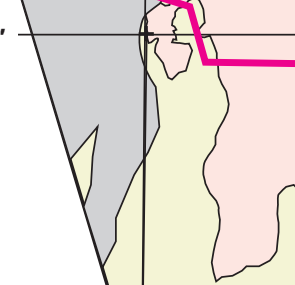

FIELD

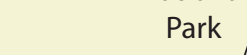

2003

San

uis 


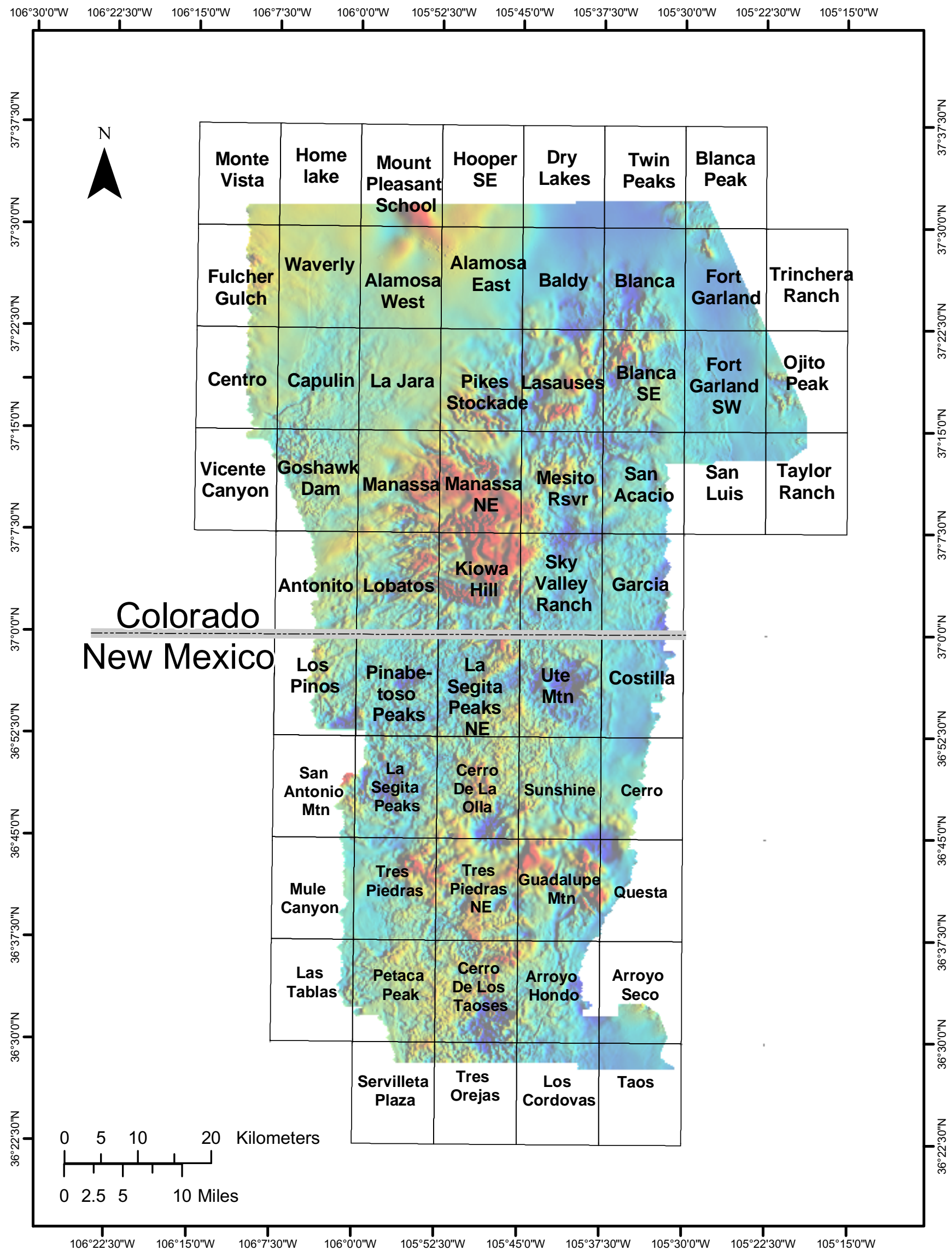

Figure 2. Index map of 1:24,000 scale quadrangle areas. 